\title{
Sustainable Integrated Approach for Management of Fusarium Wilt of Tomato Caused by Fusarium oxysporum f. sp. lycopersici (Sacc.) Synder and Hansen
}

\author{
Ravindra Singh ${ }^{1}$, S. K. Biswas ${ }^{1}$, Devesh Nagar ${ }^{1}$, Jaskaran $\operatorname{Singh}^{1}$, Morajdhwaj Singh ${ }^{1} \&$ Yogesh Kumar Mishra ${ }^{1}$ \\ ${ }^{1}$ Department of Plant Pathology, C.S.A. University of Agriculture \& Technology, Kanpur 208002, Uttar Pradesh, \\ India \\ Correspondence: S. K. Biswas, Department of Plant Pathology, C.S.A. University of Agriculture \& Technology, \\ Kanpur 208002, Uttar Pradesh, India. E-mail: samirkrbiswas@rediffmail.com
}

Received: July 11, 2014 Accepted: January 13, 2015 Online Published: January 21, 2015

doi:10.5539/sar.v4n1p138 URL: http://dx.doi.org/10.5539/sar.v4n1p138

\begin{abstract}
Integration of different methods for sustainable management of Fusarium wilt of tomato revealed that all the treatments were able to significantly reduce the disease severity over control. Among the treatments, the minimum disease severity was recorded in the $\mathrm{T}_{3}$ treatment where treatment was given as seed treatment with $T$. harzianum + soil application of neem cake powder + foliar spray of carbendazim, representing the value 4.82, 8.23, 12.37 and 16.37 per cent against 10.75, 14.84, 20.00 and 25.75 per cent in case of control at 30, 45, 60 and 75 days age of plant, respectively. Integrated approach has also been able to increase shoot length as $27.00,42.15$, 54.98 , and $65.07 \mathrm{~cm}$ at 30,45, 60 and 75 days age of plant, respectively whereas in case of control it was 18.60 , $25.70,34.63$ and 44.29. Similarly, fresh and dry shoot and root weight have also been found increased in case of integrated approaches. Biochemical analysis of the treated plants revealed that highest soluble protein and total phenol content is observed in T3 treatment (Seed treatment with T. harzianum + soil treatment with neem cake powder and foliar spray with carbendazim), showing $37.85,36.78$ and $35.76 \mathrm{mg} / \mathrm{gm}$ of fresh leave of protein and $2.40,2.14$ and $2.04 \mathrm{mg} / \mathrm{gm}$ of fresh leave of phenol at 30, 45 and 60 days age of plant. As per yield is concerned, it has found that the maximum yield was obtained per plant from the treatment given as seed treatment with $T$. harzianum + soil treatment with neem cake powder + foliar spray with carbendazim, showing the value of $500 \mathrm{~g}$ per plant which was followed by the treatment given as seed treatment with $T$. harzianum + soil treatment with neem cake powder + foliar spray with neem leaf extract showing $470 \mathrm{~g}$ per plant.
\end{abstract}

Keywords: fusarium wilt, integrated approach, growth parameter, biochemical changes, disease severity

\section{Introduction}

Tomato (Lycopersicon esculentum L. Krust) belongs to family Solanaceae is the most valued vegetable crop in the world and known as protective food because of its special nutritive value and its widespread production. The largest area and production of tomato in the world is China which occupying 871235000 hectares with a production of 41879684000 tons. But highest productivity is come out from USA which is 81.0 ton/ha. In India, total production of tomato is 16826.0 thousand tons which comes from 865.0 thousand hectors of land (Source: Indian Horticulture database 2010-11). The maximum area and production of tomato in India is Andhra Pradesh which occupying 296300 hectares with a production of 5926200 tons, but highest productivity is found in Karnataka which is 34.30 tons/ha (Source: Indian Horticulture database 2010-11). The productivity of tomato in India is very low as compared to other countries of the world. One of the main constraints to tomato cultivation is disease which is caused by viruses, bacteria, nematodes, fungi etc. Among diseases, Fusarium wilt caused by Fusarium oxysporum f. sp. lycopersici Synder and Hansen, is the most important which causes serious economic loss in all tomato growing areas of the world. The management of the disease can be done through cultural practices (Katan, 1989), use of resistant varieties (Singh \& Singh 2000; Rodriguez et al., 2003), chemical measures (Zindan et al., 2000), biological control (Gnanamanikram, 2002; Myresiotis et al., 2012; Bansal et al., 2004).

Cultural practices like field sanitation, deep summer ploughing, soil solarization, soil amendments and crop rotation etc. can minimize the possibility of disease but cannot completely control the disease in standing crops. 
Other alternative methods of controlling the disease have to be explored biological control. In this context, Trichoderma harzianum, Trichoderma viride, C. globosum \& Gliocladium virens have been exploited for management of diseases but biological control alone cannot manage the disease completely because a little fluctuation in temperature, $\mathrm{pH}$, moisture, etc. largely affects the efficacy of bio-agent. The use of resistant variety is another important method which is reliable and cheap for management of plant disease but due to development of new races of the pathogen, the resistant variety becomes susceptible one.

Hence, the use of fungicides is the last and only method for plant disease management. But continuous use of fungicide may develop resistant strain of the pathogen which has also adverse effect of tomato fruits as well as human health. Since, all the methods have some limitations' no single method can manage the disease effectively. So an integration of available methods is mandatory for sustainable management of disease. Therefore, the study was undertaken in the present investigation.

\section{Material and Methods}

\subsection{Preparation of Neem Leaves Extract}

The fresh healthy neem leaves were collected from the University Campus. The leaves were washed in the distilled water and then dried by blotter paper. After washing, the big leaves were cut into small pieces. The leaves were then crushing in pestle and mortar by using distilled water at 1:5 ratios. The pulverized mass was squeezed through 3 folds of fine cotton cloth. The extract was then diluted in water at 1:5 ratios and used for spray as per treatment given below.

\subsection{Seed Treatment}

Tomato seeds of variety Azad T- 6 were used to conduct the experiment. About 2 gm of tomato seeds were placed in each Petri plate containing spore suspension of T. harzianum@ concentration of spore 107/ $\mathrm{ml}$. The seeds were kept in petriplates for overnight. After $24 \mathrm{hrs}$, the seeds were taken out from petriplate and were dried in shade. The treated seeds were used for conducting the present experiment.

\subsection{Effects of Integrated Approach on Tomato Cultivation}

The experiment was conducted in the glasshouse complex, Department of Plant Pathology, C. S. Azad University of Agriculture and Technology Kanpur. The tomato variety Azad T-6 were sown in the glasshouse in $45 \mathrm{~cm}$ earthen pots, which was previously filled with a mixture of sandy loam and farm yard manure in the ratio of 2:1. The treatments were given as:

$\mathbf{T}_{\mathbf{1}}=$ Seed treatment with Trichoderma harzianum@4gm $/ \mathrm{kg}$ of seed

$\mathbf{T}_{\mathbf{2}}=$ Soil treament with neem kernel cake powder (NKCP)@7g/pot/plant

$\mathbf{T}_{3}=\mathrm{T}_{1}+\mathrm{T}_{2}+$ foliar spray of carbendazim @ $1 \mathrm{gm} /$ lit of water

$\mathbf{T}_{4}=\mathrm{T}_{1}+\mathrm{T}_{2}+$ foliar spray of Neem leaf extract@1:5 ratio (leaf extract : water)

$\mathbf{T}_{5}=\mathrm{T}_{1}+$ Foliar spray of Carbendazim $@ 1 \mathrm{gm} /$ lit of water

$\mathbf{T}_{\mathbf{6}}=\mathrm{T}_{1}+$ foliar spray of Neem leaf extract $@ 1: 5$ ratio (leaf extract : water)

$\mathbf{T}_{7}=$ Control (Fusarium oxysporium @ 2 ml/plant)

In each pot, 5 seeds were sown and watered regularly. Four replications per treatment and four pots were sown with untreated seeds served as control. Observations pertaining to effect of different treatments were recorded as per following parameters and days.

1. Plant height $(\mathrm{cm})$ at $30,45,60$ and 75 days after transplanting

2. Disease severity (\%) at $30,45,60$ and 75 days after transplanting

3. Root length $(\mathrm{cm})$ ninety days after transplanting

4. Fresh weight of shoot $(\mathrm{g})$ ninety days after transplanting

5. Dry weight of shoot $(\mathrm{g})$ ninety days after transplanting

6. Fresh weight of root (g) ninety days after transplanting

7. Dry root weight $(\mathrm{g})$ ninety days after transplanting

8. Yield plant (g) 


\subsection{Root and Shoot Length}

\subsubsection{Shoot Length}

Tomato seeds treated with $T$. harzianum were sown in earthen pots in the glasshouse and shoot length was measured 30, 45, 60, 75 days age of tomato plants with the help of scale.

\subsubsection{Root Length}

The root length tomato was measured at 90 days age of plant. Prior to measure the root lengths of tomato plants, pots were irrigated and the seedlings were up rooted carefully, roots of seedlings were separated from the shoots and washed with water to remove soil particles and then root length $(\mathrm{cm})$ were measured with the help of scale.

\subsection{Measurement of Disease Severity}

The disease incidence was measure after 15 days of final spraying. The disease severity was recorded by $0-4$ scale as described by Weitang et al., (2004), where zero representing no infection and four denoting plants completely infected. Three replications were maintained for each treatment. The $0-4$ scale of the disease severity was classified as follows:

0 - No infection.

1 - Slight infection which is about $25 \%$ of full scale, one or two leaves became yellow.

2- Moderate infection, two or three leaves became yellow, $50 \%$ of leaves became wilted.

3 - Extensive infection, the all plant leaves became yellow, $75 \%$ of leaves become wilted, and growth is inhibited.

4 - complete infection, the whole plant leaves become yellow, $100 \%$ of leaves become wilted, and the plants die.

The percentage of disease incidence was determined using the formula given by Weitang et al. (2004)

$$
\text { disease incidence }(\%)=\left[\frac{\left(\sum \text { scale } \times \text { number of plants infected }\right)}{(\text { highest scale } \times \text { total number of plants })}\right] \times 100
$$

\subsubsection{Fresh Weight}

Ninety days after transplanting, the shoots and roots of tomato plant were weighted on an electronic balance and the data was recorded as $\mathrm{mg}$.

\subsubsection{Dry Weight}

The fresh plant sample of ninety days after transplanting being collected and then shoots and roots were dried in an oven at $70{ }^{\circ} \mathrm{C}$ until constant weight. It was then weighted on an electronic balance and the data was recorded as $\mathrm{mg}$.

\subsection{Biochemical Analysis of Tomato Plant}

Analysis of biochemical changes in tomato plant due to integration of different methods was carried out to determine the change in biomolecules like soluble protein and phenol at 21, 42 and 63 days age of tomato plant.

\subsection{Estimation of Total Phenols}

The accumulation of phenols in tomato plant grown in glass house complex was estimated at 21, 42 and 63 days age of plant following the procedure developed by Bray and Thorpe (1954) with slight modification. In this method, the total phenols estimation was carried out with Folin-Ciocalteu reagent (FCR), which was measured at $650 \mathrm{~nm}$ calorimetrically.

Exactly, $1.0 \mathrm{~g}$ of tomato leaves were ground in a pestle and mortar along with $80 \%$ ethanol $(1: 10 \mathrm{w} / \mathrm{v})$. It was then centrifuged at $10,000 \mathrm{rpm}$ for 30 minutes at room temperature in order to homogenate the suspension. Supernatant was separated and re-extracted with 5 times volume of $80 \%$ ethanol, centrifuged and the supernatant were pooled. It was then evaporated near to dryness and residues were dissolved in $5 \mathrm{ml}$ of distilled water. Different aliquots were pipette out into test tubes and the volume in each tube was made to $3 \mathrm{ml}$ with distilled water. A test tube with $3 \mathrm{ml}$ distilled water served as blank. Subsequently, $0.5 \mathrm{ml}$ of FCR was added and after three minutes, $2 \mathrm{ml}$ of $20 \% \mathrm{Na}_{2} \mathrm{CO}_{3}$ solution was thoroughly mixed in each tube. After that the tubes were placed in boiling water for $1 \mathrm{~min}$ and then cooled at room temperature. Then absorbance at $650 \mathrm{~nm}$ against blank was measured using Ultra Violet Visible (UV-VIS) spectrophotometer and the standard curve using different 
concentration of catechol was prepared. From the standard curve the concentration of phenols in the test sample was determined and expressed as $\mathrm{mg} / \mathrm{g}$ of sample materials.

\subsection{Estimation of Total Soluble Protein}

\subsubsection{Protein Extraction}

Tomato leaves were harvested from plants at 21, 42 and 63 days age of plant and then washed with distilled water several times and blotter dried. A quantity of $1.0 \mathrm{gm}$ of each sample was cut into small pieces and ground in pestle and mortar using alkaline copper as extraction buffer. The concentration was kept 1:5(w/v). Alkaline copper solution was prepared by mixing $20 \%$ sodium carbonate in $0.1 \mathrm{~N} \mathrm{NaOH}$ and $0.5 \%$ copper sulphate in sodium potassium tartrate. The suspension was centrifuged at $10,000 \mathrm{rpm}$ for 30 minutes at $4{ }^{\circ} \mathrm{C}$. The supernatant was collected and used for quantification of protein.

\subsubsection{Quantification of Protein}

The method developed by Lowry et al. (1951) was used with slight modification for quantification of the total soluble protein content. Different aliquots of working standard solution of Bovine Serum Albumin were pipette out into a series of test tubes. Similarly, same volumes of sample extracts were also pipette out and kept in other test tubes separately. Then volume in all the tubes was made up to $1 \mathrm{ml}$ with distilled water. A tube with $1 \mathrm{ml}$ of distilled water served as a blank. Later on, $5 \mathrm{ml}$ of alkaline copper solution was added in each test tube and incubated at room temperature for $10 \mathrm{~min}$. Thereafter, $0.5 \mathrm{ml}$ of FCR was mixed well and incubated at room temperature for $30 \mathrm{~min}$ in dark place. The absorbance at $660 \mathrm{~nm}$ against the blank was read. The standard graph of BSA was drawn to calculate the amount of soluble protein in different samples. Protein estimated was represented as $\mathrm{mg} / \mathrm{g}$ of fresh leaf samples.

\subsection{Yield/Plant}

The edible fruits were harvested twice a week from each selected plant and weighted with the help of physical balance. The total weight of all picking was recorded after adding weight of fruits at each picking.

\section{Results and Discussion}

\subsection{Disease Severity}

The data presented in Table 1 found that all the treatments were able to significantly reduce the disease severity over control at 30, 45, 60 and 75 days age of plant. Among the treatments, the minimum disease severity was recorded in the $\mathrm{T}_{3}$ treatment where treatment was given as seed treatment with $T$. harzianum + soil application of neem cake powder + foliar spray of carbendazim, representing the value 4.82, 8.23, 12.37 and 16.37 per cent at $30,45,60$ and 75 days age of plant, respectively.

Table 1. Efficacy of integrated approach on disease severity of Fusarium wilt of tomato at 30, 45, 60 and 75 days age of plant

\begin{tabular}{llllll}
\hline Treatments & \multicolumn{4}{c}{ Disease severity (\%) } \\
\hline & & 30 DAT & 45 DAT & 60 DAT & 75 DAT \\
\hline $\mathrm{T}_{1}$ & Seed treatment with Trichoderma & $9.45(17.85)^{*}$ & $12.00(20.20)$ & $17.00(24.27)$ & $22.31(28.19)$ \\
& harzianum & & & & \\
$\mathrm{T}_{2}$ & Soil treatment with neem cake powder & $10.75(19.14)$ & $14.84(22.66)$ & $20.00(26.56)$ & $25.75(30.44)$ \\
$\mathrm{T}_{3}$ & $\mathrm{~T}_{1}+\mathrm{T}_{2}+$ carbendazim & $4.82(12.68)$ & $8.23(16.68)$ & $12.37(20.60)$ & $16.35(23.85)$ \\
$\mathrm{T}_{4}$ & $\mathrm{~T}_{1}+\mathrm{T}_{2}+$ neem leaf extract & $6.56(14.84)$ & $9.35(17.81)$ & $14.45(22.35)$ & $18.30(25.32)$ \\
$\mathrm{T}_{5}$ & $\mathrm{~T}_{1}+$ carbendazim & $7.58(15.99)$ & $10.50(18.90)$ & $15.39(23.09)$ & $19.29(26.05)$ \\
$\mathrm{T}_{6}$ & $\mathrm{~T}_{1}+$ neem leaf extract & $8.12(16.55)$ & $10.89(19.27)$ & $16.12(23.68)$ & $19.99(26.56)$ \\
$\mathrm{T}_{7}$ & Control & $12.00(20.24)$ & $15.86(23.41)$ & $21.40(27.55)$ & $26.69(31.10)$ \\
& CD $(0.05)$ & 1.2 & 1.703 & 1.393 & 1.496 \\
& S.E.(d) & 0.5784 & 0.8213 & 0.6697 & 0.7183 \\
\hline
\end{tabular}

\footnotetext{
*Paratheses value is angular value.
} 
The $\mathrm{T}_{2}$ treatment (soil treatment with neem cake powder) showing the value of 10.75, 14.84, 20.00 and 25.75 per cent disease severity, indicating maximum disease severity among the treatments at 30, 45, 60 and 75 days age of plant. The rest of the treatments were also showing superior over control in respect to minimum disease severity showing 12.00, 15.86, 21.40 and 26.69 percent disease severity in case of control. Kumar and Dubey (2001) reported that integrated seed treatment with fungicide and antagonists protect plant from $F$. o. f. sp. lycopersici. Biological control integrated with fungicidal treatment has been found more reliable approach to manage soil borne plant pathogen was reported by Mukhopadhyay, (1987). Myresiotis et al. (2012) reported that when bacilli PGPR strains were combined with pesticides, there was an increased suppression of $F$. o.f. sp. radicis-lycopersici (Forl) on tomato plants, and thus they may prove to be important components in FCRR integrated management. Someya et al. (2006) reported that combined application of benomyl with Pseudomonas fluorescens strain LRB3W1was more effective than treatment with the bacterium alone for management of tomato wilt.

\subsection{Shoot Length}

The data presented in the Table 2 showed that all the treatments were able to significantly increased shoot length over control at 30, 45, 60 and 75 days age of plant. Among the treatments, the maximum shoot length was recorded in the $\mathrm{T}_{3}$ treatment (seed treatment with T. harzianum + soil application of neem cake powder + foliar spray of carbendazim), representing $27.00,42.15,54.98$, and $65.07 \mathrm{~cm}$ shoot length against $18.60,25.70,34.63$ and $44.29 \mathrm{~cm}$ in case of control at 30, 45, 60 and 75 days age of plant, respectively. Among the treatments, minimum shoot length was recorded in $T_{2}$ treatment with the value 21.00 and $29.87 \mathrm{~cm}$ (soil treatment with neem cake powder ) at 30 and 45 days age of plant where as at 60 and 75 days age of plant it was $T_{1}$ treatment, where treatment were given as only seed treatment with $T$. harzianum representing the value of $23.11,37.18,43.50$ and $53.86 \mathrm{~cm}$. From the table, it is cleared that the effect of seed treatment with $T$. harzianum has growth promoting effect in early age of plant. The data on the table also showed that all the treatments were able to increase shoot length over control. Datnoff et al. (1995) found that Trichoderma spp. stimulate the growth of tomato plants. Growth promoting effect of bioagents has also been reported by several workers (Biswas et al., 2000, Kumawat et al., 2010, Rajik et al., 2012, Sen, 1999). Mondal et al. (1999) also used two metabolites isolated from Aspergillus niger AN27, a bio-control agent, and identified as maleic acid (compound I) and 2-methylene-3-hexylbutanedioic acid (compound 2) and found that both the compounds increased germination and improved crop vigor. They also found that Compound I was more effective for increase in germination and shoot length, whereas compound 2 had relatively greater role in increasing the root length and biomass of cauliflower seedlings.

Table 2. Efficacy of integrated approach on shoot length of tomato plant at different days of interval

\begin{tabular}{llllll}
\hline Treatments & \multicolumn{4}{c}{ Shoot length (cm) at days of plant } \\
\hline & & 30 DAT & 45 DAT & 60 DAT & 75 DAT \\
\hline $\mathrm{T}_{1}$ & Seed treatment with Trichoderma harzianum & 23.11 & 37.18 & 43.50 & 53.86 \\
$\mathrm{~T}_{2}$ & Soil treatment with neem cake powder & 21.00 & 29.87 & 50.19 & 60.13 \\
$\mathrm{~T}_{3}$ & $\mathrm{~T}_{1}+\mathrm{T}_{2}+$ carbendazim & 27.00 & 42.15 & 54.98 & 65.07 \\
$\mathrm{~T}_{4}$ & $\mathrm{~T}_{1}+\mathrm{T}_{2}+$ neem leaf extract & 25.23 & 40.17 & 53.00 & 63.35 \\
$\mathrm{~T}_{5}$ & $\mathrm{~T}_{1}+$ carbendazim & 21.55 & 35.80 & 47.63 & 57.89 \\
$\mathrm{~T}_{6}$ & $\mathrm{~T}_{1}+$ neem leaf extract & 21.30 & 30.98 & 43.53 & 54.51 \\
$\mathrm{~T}_{7}$ & Control & 18.60 & 25.70 & 34.63 & 44.29 \\
& $\mathrm{CD}(0.05)$ & 1.6366 & 2.2696 & 2.0427 & 3.1140 \\
& $\mathrm{SE}(\mathrm{d})$ & 0.7868 & 1.0911 & 0.9821 & 1.4970 \\
\hline
\end{tabular}

\subsection{Root Length}

Ninety days after sowing, the tomato plant was uprooted and the root length was measured separately by using measuring scale. The data presented in the Table 3 found that the maximum root length was recorded in the $\mathrm{T}_{3}$ treatment where seed was treated with T.harzianum + soil treatment with neem cake powder + foliar spray of carbendazim showing the value of $19.11 \mathrm{~cm}$ which was followed by $\mathrm{T}_{4}$ treatment, comprising of seed treatment 
with T.harzianum + soil treatment with neem cake powder + foliar spray with neem leaf extract with the value of $18.40 \mathrm{~cm}$. Among the treatments, the minimum root length was found in $\mathrm{T}_{2}$ treatment with the value of 13.50 $\mathrm{cm}$ where only neem cake powder was given as soil treatment. From the table, it is also cleared that all the treatments were able to increase root length over control. Shanmugaiah et al. (2009) reported that T. viride was found to be more effective than $P$. fluroescens on shoot and root length elongation and enhanced seed germination.

\subsection{Fresh and Dry Shoot Weight}

Fresh shoots of tomato plant were weighted on an electronic balance and the data presented in the Table 3 showed that all the treatments were able to increase the fresh shoot weight of tomato over control. The maximum fresh shoot weight was recorded in combination of seed treatment with $T$. harzianum+ soil treatment with neem cake powder + foliar spray of carbendazim, representing $40.50 \mathrm{~g}$ against $29.50 \mathrm{~g}$ in case of control. The combined effect of treated with $T$. harzianum + soil treatment with neem cake powder + foliar spray of neem leaf extract was showing $38.80 \mathrm{~g}$ fresh weight at 90 days age of plant which is the second highest among the treatments.

As per dry shoot weight is enhanced, it has found that the maximum dry shoot weight $(9.03 \mathrm{~g})$ was recorded in $\mathrm{T}_{3}$ treatment (seed treatment with $T$. harzianum + soil treatment with neem cake powder + foliar spray with carbendazim) followed by $\mathrm{T}_{4}$ treatment (seed treatment with $T$. harzianum + soil treatment with neem cake powder + foliar spray with neem leaf extract) showing $8.6 \mathrm{~g}$ dry weight at 90 days age of plant (Table 3 ). $\mathrm{T}_{5}$ (seed treatment with $T$. harzianum + foliar spray with carbendazim) and $\mathrm{T}_{6}$ (seed treatment with $T$. harzianum + foliar spray with neem leaves extract) treatments were showing $7.9 \mathrm{~g}$ and $6.00 \mathrm{~g}$ in dry shoot weight, respectively. Alwathnani and Kahkashan (2012) reported that seed treatment with bioagents (Aspergillus niger, Penicillium citrinum, Penicillium sp. and Trichoderma harzianum) significantly increased plant height, fresh weight and dry weight of plant. They also found that increased content of chlorophyll and decrease the disease severity of Fusarium wilt in all treated plant. Ozbay and Newman (2004) also reported that seeling treated with $T$. harzianum increases seedling emergence, number of true leaves, fresh and dry weights of roots and shoots, stem caliper and shoot height. Sundaramoorthy and Balabaskar (2013) also observed that tomato plants treated with $T$. harzianum (ANR-1) stimulate plant height by $73.62 \mathrm{~cm}$ and increased the dry weight by $288.38 \mathrm{~g}$ in comparison to untreated control.

Table 3. Efficacy of integrated approach on root length, fresh weight of root and shoot, dry weight of root and shoot of tomato at 90 days age of plant

\begin{tabular}{|c|c|c|c|c|c|c|c|}
\hline & nents & $\begin{array}{l}\text { Root } \\
\text { length }\end{array}$ & $\begin{array}{l}\text { Fresh } \\
\text { Root } \\
\text { weight }\end{array}$ & $\begin{array}{l}\text { Dry Root } \\
\text { weight }\end{array}$ & $\begin{array}{l}\text { Fresh } \\
\text { Shoot } \\
\text { weight }\end{array}$ & $\begin{array}{l}\text { Dry } \\
\text { Shoot } \\
\text { weight }\end{array}$ & $\begin{array}{l}\text { Yield } \\
\text { /plant (g) }\end{array}$ \\
\hline $\mathrm{T}_{1}$ & $\begin{array}{l}\text { Seed treatment with } \\
\text { Trichoderma harzianum }\end{array}$ & 14.10 & 7.01 & 2.50 & 34.56 & 6.00 & 405 \\
\hline $\mathrm{T}_{2}$ & $\begin{array}{l}\text { Soil treatment with neem } \\
\text { cake powder }\end{array}$ & 13.50 & 6.50 & 2.00 & 33.50 & 5.60 & 390 \\
\hline $\mathrm{T}_{3}$ & $\mathrm{~T}_{1}+\mathrm{T}_{2}+$ carbendazim & 19.11 & 10.50 & 3.59 & 40.50 & 9.10 & 500 \\
\hline $\mathrm{T}_{4}$ & $\begin{array}{l}\mathrm{T}_{1}+\mathrm{T}_{2}+\text { neem leaf } \\
\text { extract }\end{array}$ & 18.40 & 9.80 & 3.40 & 38.80 & 8.60 & 470 \\
\hline $\mathrm{T}_{5}$ & $\mathrm{~T}_{1}+$ carbendazim & 17.70 & 8.50 & 3.00 & 36.90 & 7.90 & 440 \\
\hline $\mathrm{T}_{6}$ & $\mathrm{~T}_{1}+$ neem leaf extract & 15.30 & 8.00 & 2.70 & 35.70 & 6.50 & 420 \\
\hline $\mathrm{T}_{7}$ & Control & 10.30 & 3,50 & 0.48 & 29.50 & 3.40 & 325 \\
\hline & $\mathrm{CD}(0.05)$ & 0.9532 & 0.4585 & 0.2269 & 1.8156 & 0.7810 & 16.0485 \\
\hline & $\mathrm{SE}(\mathrm{d})$ & 0.4583 & 0.2202 & 0.1095 & 0.8729 & 0.3755 & 7.7152 \\
\hline
\end{tabular}




\subsection{Fresh and Dry Root Weight}

Similarly, fresh roots of tomato plant were also weighed on an electronic balance and the data represented in the Table 3 showed that all the treatments were able to increase the fresh root weight of tomato plant over control. The maximum fresh root weight was recorded in combine treatment of seed treatment with $T$. harzianum + soil treatment with neem cake powder + foliar spray with carbendazim, representing $10.50 \mathrm{~g}$ against control as $3.50 \mathrm{~g}$. The treatment comprises of seed treatment with $T$. harzianum + soil treatment with neem cake powder + foliar spray of neem leaf extract was showing $9.80 \mathrm{~g}$ fresh root weight at 90 days age of plant which is the second highest among the treatment.

On the other hand, dry shoot weight of tomato showed that the maximum dry root weight $(3.59 \mathrm{~g})$ was recorded in $\mathrm{T}_{3}$ treatment (seed treatment with $T$. harzianum + soil treatment with neem cake powder + foliar spray with carbendazim) followed by $\mathrm{T}_{4}$ treatment (seed treatment with $T$. harzianum + neem cake powder + foliar spray with neem leaf extract) showing $3.40 \mathrm{~g}$ dry root weight at 90 days age of plant. $\mathrm{T}_{5}$ (seed treatment with $T$. harzianum + foliar spray with carbendazim) and $\mathrm{T}_{6}$ treatment (seed treatment with $T$. harzianum + foliar spray with neem leaves extract ) were showing $3.00 \mathrm{~g}$ and $2.70 \mathrm{~g}$ dry root weight, respectively.

Shanmugaiah et al. (2009) observed cotton seeds treated with T. viride increased seed germination, root and shoot length, fresh and dry weight and vigour index over control. Bombiti Nzanza et al. (2011) studied on biomass production in 6-week old tomato seedlings as influenced by T. harzianum and Arbuscular mycorrhizal fungi (AMF). Chandanie et al. (2009) demonstrated that, the combined inoculation of AMF with Trichoderma synergistically increased dry shoot mass when compared with inoculation of Trichoderma and AMF alone.

\subsection{Biochemical Changes in Plant Due to Adaptation of Integrated Approach}

To evaluate the biochemical changes associated with adaptation of integrated approach, the leaves of the treated plants were used. The total soluble protein and total phenol content of the seedling were estimated. The results obtained are shown in Table 4.

\subsection{Soluble Proteins and Total Phenol Content}

The result presented in the Table 4 shows that all treatments are significantly increased the total soluble protein content in tomato plant as compared to control. The highest soluble protein content is observed in T3 treatment (Seed treatment with T. harzianum + soil treatment with neem cake powder and foliar spray with carbendazim), showing $37.85,36.78$ and $35.76 \mathrm{mg} / \mathrm{gm}$ of fresh leave at 30,45 and 60 days age of plant, which was followed by T4 treatment (Seed treatment with T. harzianum + soil treatment with neem cake powder and foliar spray with neem leaf extract), representing $36.38,35.94$ and $35.25 \mathrm{mg} / \mathrm{gm}$ of fresh leave at 30,45 and 60 days age of plant. Similarly increase content of total phenol was also found in case of seed treatment with T. harzianum + soil treatment with neem cake powder and foliar spray with carbendazim, representing $2.40,2.14$ and $2.04 \mathrm{mg} / \mathrm{gm}$ of fresh leave at 30, 45 and 60 days age of plant. Among the treatment, minimum phenol content was found in $\mathrm{T}_{1}$ treatment where only seed was treated with T. harzianum. From the table it is also clear that the maximum amount of both soluble protein and total phenol content were found at 30 days age of plant and after that it was gradually decrease, indicating soluble protein and total phenol content were inversely proportionate with age of the plant.

The finding from the Table 1 revealed that disease severity continuously increase with age of the plant whereas, from the Table 4, it has found that soluble protein and total phenol content were decreases with age of the plant. Therefore it may be concluded from both the tables that increase content of total soluble protein and phenol content in plant decreases the disease severity. Accumulation of soluble proteins and total phenols are considered the expression of defence response in plants (Matern \& Kneusal, 1988, Biswas et al., 2012, Arzoo et al., 2012). Vidyasekaran (1974) reported enhanced quantity of phenols in ragi plants resistant to Helminthosorium tetramera. Boller (1985) reported association of protein with plant defence against fungi and bacteria. Biswas et al. (2003) also reported that some new proteins were associated with resistance to Bipolaris sorokiniana induced by crude extracts of Chaetomium globosum. Phenols are involved in disease resistance in many ways like hypersensitive cell death or lignifications of cell walls or increased content of phenol (Nicholson and Hammerschimdt, 1992; Adesh, 2010; Kumawat, 2008). 
Table 4. Effect of integrated approaches on total soluble protein and phenol content of tomato leaves at 30,45 and 60 days age of plant

\begin{tabular}{|c|c|c|c|c|c|c|c|}
\hline \multirow{2}{*}{$\begin{array}{l}\text { Sl. } \\
\text { No. }\end{array}$} & \multirow{2}{*}{ Treatment } & \multicolumn{3}{|c|}{$\begin{array}{c}\text { Total soluble protein content } \mathrm{mg} / \mathrm{g} \\
\text { fresh leaves }\end{array}$} & \multicolumn{3}{|c|}{$\begin{array}{c}\text { Total phenol content } \mathrm{mg} / \mathrm{g} \\
\text { fresh leaves }\end{array}$} \\
\hline & & 30 days & 45 days & 60 days & 30 days & 45 days & 60 days \\
\hline 1 & $\begin{array}{l}\mathrm{T} 1=\text { Seed treatment with } \\
\text { Trichoderma harzianum }\end{array}$ & 29.65 & 28.4 & 27.84 & 1.76 & 1.6 & 1.58 \\
\hline 2 & $\begin{array}{l}\mathrm{T} 2=\text { Soil treatment with neem } \\
\text { cake powder }\end{array}$ & 32.74 & 29.65 & 30.26 & 1.86 & 1.75 & 1.7 \\
\hline 3 & $\mathrm{~T} 3=\mathrm{T}_{1}+\mathrm{T}_{2}+$ carbendazim & 37.85 & 35.76 & 36.78 & 2.4 & 2.14 & 2.04 \\
\hline 4 & $\mathrm{~T} 4=\mathrm{T}_{1}+\mathrm{T}_{2}+$ neem leaf extract & 36.38 & 35.25 & 35.94 & 2.3 & 2.06 & 1.98 \\
\hline 5 & $\mathrm{~T} 5=\mathrm{T}_{1}+$ carbendazim & 30.74 & 28.5 & 29.12 & 1.86 & 1.78 & 1.7 \\
\hline 6 & $\mathrm{~T} 6=\mathrm{T}_{1}+$ neem leaf extract & 30.56 & 28.45 & 28.94 & 1.8 & 1.68 & 1.6 \\
\hline 7 & $\mathrm{~T} 7=$ Control & 21.8 & 22.26 & 19.78 & 1.52 & 1.54 & 1.4 \\
\hline
\end{tabular}

\subsection{Yield}

The fruit of tomato were harvested and the yield was separately weighted for each treatment (Table 3). It has found that the maximum yield was recorded per plant in $T_{3}$ treatment where treatment was given as seed treatment with $T$. harzianum + soil treatment with neem cake powder + foliar spray with carbendazim. The $\mathrm{T}_{4}$ treatment as combination of seed treatment with $T$. harzianum + soil treatment with neem cake powder + foliar spray with neem leaf extract showing $470 \mathrm{~g}$ per plant representing second highest among the treatments. The $\mathrm{T}_{5}$ (seed treatment with T. harzianum + foliar spray with carbendazim) and T6 (seed treatment with T. harzianum + foliar spray with neem leaves extract) treatments represented $440,420 \mathrm{~g}$ per plant, respectively. From the table, it is cleared that all treatments significantly increased tomato yield over control. Surulirajan and Kandhaari (2003) found that the integrated approach lower down the disease incidence of rice sheath blight and increase rice yield. Agilogba and babalola (2013) reported that the integration of plant-growth-promoting rhizobacteria, acibenzolar-S-methyl and hymexazol for control of Fusarium crown and root rot on tomato. Biswas et al. (2009) also found that seed treatment with streptocycline $(100 \mathrm{ppm})$ and foliar spray with streptocycline in combination of copper oxychloride $(100 \mathrm{ppm}+500 \mathrm{ppm})$ gave the best management strategies for management of bacterial leaf blight and also increase higher yield. Biswas et al. (2008) also reported that seed treatment with $T$. harzianum and foliar spray with fungicides is one of the best strategies to manage brown spot and sheath blight of paddy and also increase higher yield.

\section{References}

Adesh, K., \& Biswas, S. K. (2010). Biochemical evidence of induced resistance in tomato against Fusarium wilt through inorganic chemicals. J. Mycopathol. Re, 48(2), 213-219.

Agilogba, C. F., \& Babalola, O. O. (2013). Integrated management strategies for tomato Fusarium wilt. Biocontrol science, 18(3)117-127. http://dx.doi.org/10.4265/bio.18.117

Alwathnani, H., A., \& Kahkashan, P. (2012). Biological control of Fusarium wilt of tomato by antagonist fungi and cyanobacteria. African J. Biotechnology, 11(5), 1100-1105.

Arzoo, K., Samir, K. B., \& Mohd, R. (2012). Biochemical evidences of defence response in tomato against Fusarium wilt induced by plant extracts. Plant Pathology Journal, 11(2) 42-50. http://dx.doi.org/10.3923/ppj.2012.42.50

Bansal, R. K. Majumdar, V. L., \& Bhatnagar, K. (2004). Antagonism of Azotobacter chroococcum to Fusarium oxysporum f. sp. lycopersici causing wilt of tomato Abstract. J. Mycol. Pl. Pathol, 470.

Biswas, S. K., Pandey, N. K., \& Mohd, R. (2012). Inductions of defense response in tomato against Fusarium wilt through inorganic chemicals as inducers. Plant Pathology \& Microbiology, 3(4), 1-7

Biswas, S. K., Rai, M., \& Srivasatva, S. S. L. (2009). Evaluation of antibiotics in combination with chemicals for management of bacterial blight of paddy [Xanthomonas oryzae pv oryzae (Ishiyama) Dye]. Indian Phytopath, 62(1), 126-128. 
Biswas, S. K., Ratan, V., Yadav, R., \& Srivastava, S. S. L. (2008). Influence of seed treatment with biocides and foliar spray of fungicides for management of brown leaf spot (Drechslera oryzae) and sheath blight (Rhizoctonia solani) of paddy. Indian Phytopath, 61(1), 55-59.

Biswas, S. K., Srivastava, K. D., Aggarwal, R., Praveen, S.m \& Singh, D. V. (2003) Biochemical changes in wheat induced by Chaetomium globosum against spot blotch pathogen Indian Phytopathm, 56(4), 374-379.

Biswas, S. K., Srivastava, K. D., Aggarwal, R., Dureja P., \& Singh, D. V. (2000). Antagonism of Chaetomium globosum to Drechslera sorokiniana, the spot blotch pathogen of wheat. Indian Phytopath, 53, 436-440.

Boller, T. (1985). Induction of hydrolases as a defence reaction against pathogens. In J. L. Key \& T. Kosuge (Eds.), Cellular and Molecular Biology of Plant Stress, UCLA Symposia of Molecular and Cellular Biology, New Series, 22, 247-262.

Bombiti, N., Diana, M., \& Puffy, S. (2011). Tomato (Solanum lycopersicum L.) seedling growth and development as influenced by Trichoderma harzianum and arbuscular mycorrhizal fungi. African Journal of Microbiology Research, 5(4), 425-431.

Chandanie, W. A., Kubota, M., \& Hyakumachi, M. (2009). Interaction between the arbuscular mycorrhizal fungus Glomus mosseae and plant growth-promoting fungi and their significance for enhancing plant growth and suppressing damping-off of cucumber (Cucumis sativus L.). Appl. Soil Ecol., 41, 336-341. http://dx.doi.org/10.1016/j.apsoil.2008.12.006

Datnoff, L. F., Sand, N., \& Parnezny, K. (1995). Biological control of Fusarium crown and root rot of tomato in Florida using Trichoderma harzianum and Glomus intrarasices. Biol.Contl., 5, 27-231.

Gnanamanickam, S. S., Vasudevan, P., Reddy, M. S., Klorpper, J. W., \& Defago, G. (2002). Principles of biological control. Biological Control of Crop Diseases, 1-9.

Goutam, M., Prem, D., \& Bineeta, S. (1999). Fungal metabolites from Aspergillus nigerAN27 related to plant growth promotion, Indian Journal of Experimental Biology, 38, 84-87.

Katan, J. (1989). Soil temperature interaction with biotic component of vascular wilt diseases. In C. Beckman \& E. Tjamo (Ed.) The interaction of genes and environment factors in development of vascular diseases in plants( pp. 493-499). Verlag, Berlin: Springer.

Kumar, D., \& Dubey, S. C. (2001). Management of collar rot of pea by the integration of biological and chemical methods. Indian Phytopath, 54, 62-66.

Kumawat, G. L., Biswas, S. K., \& Srivastava, S. S. L. (2008). Biochemical evidence of defence response in plant induced by bio-agents against brown leaf spot pathogen. Indian Phytopath, 61(2), 197-203.

Kumawat, G. L., Biswas, S. K., \& Mohd, R. (2010). Antagonistic evaluations of Trichoderma spp. and their effect on germination and growth of paddy seedling. J. Pl. Dis.Sci, 5(1), 203-207.

Matern, U., \& Kneusal, R. E. (1988). Phenolic compounds in plant disease resistance. Phytoparasitica, 16, 153-170. http://dx.doi.org/10.1007/BF02980469

Mohd, R., Biswas, S. K., \& Muneseshwar, S. (2012). Biochemical changes in tomato due to seed treatment with biotic inducers. Bioinfilet, 9(4A), 451-453.

Mukhopadhyay, A. N. (1987). Biological control of soil borne plant pathogens by Trichoderma spp. J. Mycol. Pl. Pathol, 17, 1-9.

Myresiotis, C. K., Karaoglanidis, G. S., Vryzas, Z., \& Papadopoulou-Mourkidou, E. (2012). Evaluation of plant-growth-promoting rhizobacteria, acibenzolar-S-methyl and hymexazol for integrated control of Fusarium crown and root rot on tomato. Pest Manag. Sci, 68(3), 404-11. http://dx.doi.org/10.1002/ps.2277

Nicholson, R. L., \& Hammerschmidt, R. (1992). Phenolic compound and their role in disease resistance. Ann. Rev. Phytopathol, 30, 369-380. http://dx.doi.org/10.1146/annurev.py.30.090192.002101

Ozbay, N., \& Newman, S. E. (2004). The Effect of the Trichoderma harzianum Strains on the Growth of Tomato Seedlings. Acta Hort, 635.

Rodriguez, Mohra, M. C., J. Madira, L. M., Torres, Vila \& Cuartere, J. (2003). Yascular colonization pattern in susceptible and resistant tomato cultivars inoculated wilt Fusarium oxysporum f. sp. lycopersici race $\mathrm{O}$ and I. Plant Pathology, 52(2), 199. http://dx.doi.org/10.1046/j.1365-3059.2003.00810.x

Sen, B. (1999). Kalisena-an eco-friendly biopesticide-cum bio-fertilizer from Aspergillus niger AN 27. Division of Plant Pathology, IARI, New Delhi, 10. 
Shanmugaiah, V., Balasubramanian, N, Gomathinayagam, S., Manoharan, P. T., \& Rajendran, A. (2009). Effect of single application of Trichoderma viride and Pseudomonas fluorescens on growth promotion in cotton plants. African Journal of Agricultural Research, 4(11), 1220-1225.

Singh, A. K., \& Singh, A. (2000). Performance of tomato hybrids under submontore and low hills subtropical condition of Himachal Pradesh. Crop Research Hissar, 20(3), 539-540.

Someya, N., Tsuchiya, K., Yoshida, T., Noguchi, M. T., \& Sawada, H. (2006). Combined use of the biocontrol bacterium Pseudomonas fluorescens strain LRB3W1 with reduced fungicide application for the control of tomato Fusarium wilt. Biocontrol Sci., 11(2), 75-80. http://dx.doi.org/10.4265/bio.11.75

Sundaramoorthy, S., \& Balabaskar, P. (2013). Biocontrol efficacy of Trichoderma spp. against wilt of tomato caused by Fusarium oxysporum f. sp. Lycopersici. Journal of Applied Biology \& Biotechnology, 1(03), 036-040.

Surulirajan, M., \& Kandhaari, J. (2003). Effect of integrated treatment against rice sheath blight severity, disease incidence and yield parameter. Annals of Plant Protection Science, 11(2), 284-288.

Synder, W. C., \& Hansen, H. N. (1940). The species concept in Fusarium. Amer. J. Bot., $27,64-67$. http://dx.doi.org/10.2307/2436688

Vidhyasekaran, P. (1974). Role of phenolics in leaf spot incidence in ragi incited by Helminthosporium tetramera. Indian Phytopath., 27, 583-586.

Weitang, S., Ligang, Z., Chengzong, Y., Xiaodong, C., Liqun, Z., \& Xili, L. (2004). Tomato Fusarium wilt and its chemical control strategies in a hydroponic system. Crop protection, 23(3), 120-123.

Zindan, Z. H., Elewa, I. S., Hussain, M. I., \& Naser, Z. A. (2000). Efficacy of fungicides against Fusarium wilt fungus under laboratory and green house condition. Ann. Agri. Sci., 38(2), 1295-1305.

\section{Copyrights}

Copyright for this article is retained by the author(s), with first publication rights granted to the journal.

This is an open-access article distributed under the terms and conditions of the Creative Commons Attribution license (http://creativecommons.org/licenses/by/3.0/). 